\title{
Heuristic Potentials of Biographical Method in Historical and Phlosophical Studies
}

\author{
Askadula Galimzyanovich Sabirov
}

History and Legal Sciences Department, Philosophy and Sociology Faculty,

The Elabuga Institute of Kazan Federal University (Branch)

423606, Elabuga, Russia, the Republic of Tatarstan, Gvardeiskaya st., house 16

Email: agsabir@list.ru

\section{Doi:10.5901/mjss.2015.v6n3s3p249}

\begin{abstract}
The paper is concerned with cognitive potentials of biographical method in historical and philosophical studies. The specific nature of biographical method, its advantages and disadvantages are exposed. Multifunction opportunities of biographical method in historical and philosophical studies are described. It's shown that application of this method in historical and philosophical studies allows defining the influence of life circumstances on philosopher's views features: forming their generalized portrait.
\end{abstract}

Keywords: biographical method, biography, heuristics, potentials, historical and philosophical studies.

\section{Introduction}

Biographical method is a subject of research of many kinds of sciences. It's caused by the fact that the method involves studying scientists' biographies, revealing the impact of life circumstances on their world-view. Representatives of sociology (Gay-Voronskaya A., 2015, Rozhdestvenskaya E.Yu., 2012), psychology (Bühler, Ch.,1972, Jaspers K., 1960), physics (Sabirova, F.M., 2013) studied its potentials. They were examined in philosophy in a less degree. Nonetheless, biographical method was extensively studied and applied in the days of Aristotle, Plato and Diogenes Laertius. Afterwards it was developed and used by many philosophers, for example, Fichte I., Hegel H., Feuerbach L., V. Dilthey. After V. Dilthey biographical method was extensively studied and applied by Heidegger M., Russel B., Mead G., Denzin N., Misch G., Jaspers K. in their researches. In Russian philosophy Garin I.I., Devyatko I.F., Emelyyanov B.V., Rozhdenstvenskaya E.Yu Solovyev E.Yu studied subject-matter and potentials of biographical method in their works. The author of this paper also emphasized importance of this method among other methods of social cognition (Sabirov, A.G., 2013). The above-mentioned researchers defined essential features of biographical method, described its potentials, developed application methods. However, existing studies do not reveal and describe heuristic potentials of biographical method in specific historical and philosophical studies to the full. In our opinion, the study of biographical method, its role in historical and philosophical studies is relevant, since it makes possible to detect influence of philosophers' biographies on formation and development of their world-view, to compile philosopher's generalized portrait. The paper proposes the solution of this problem.

\section{Literature Review}

Biographical method essence and potentials in specific historical and philosophical studies were examined in ancient Greek philosophy. Diogenes Laertius was among the first who examined philosophers' biographies and revealed their impact on philosophers' world-view (Diogenes Laertius, 1979). Diogenes Laertius' ideas were endorsed and developed by many philosophers of modern history. Fichte I. expressed their general opinion. He pointed that it's impossible to comprehend philosopher's view without studying his life. He wrote that "the choice of some philosophy depends on what is a person, philosophy encapsulates the spirit of a person who chooses philosophy" (Fichte I., 1993). Afterwards Dilthey W. developed his ideas. He put an emphasis on the need for philosophers' life study, since it makes it possible to understand essential features and specific nature of one or another philosophical theory more deeply (Dilthey W., 1992). Misch G. studied people's autobiographies linked to historical period (Misch G., 1949). Denzin N. provided the definition of biographical method ("life history" method) and developed general scheme of biography analysis and description ("life histories") (Denzin N., 1989). Denzin N. stated that "...biographical method represents experience and definitions of one 
person, one group or one organization in the form, in which this person, group or organization interprets this experience" (Denzin N., 1989, P. 183). Fuchs-Heinritz W. also adhered to this definition (Fuchs-Heinritz W., 1993). Miller R. suggested another definition: "the biographical method is the collection and analysis of an intensive account of a whole life or portion of a life, usually by an in-depth, unstructured interview. The account may be reinforced by semi-structured interviewing or personal documents. Rather than concentrating upon a 'snapshot' of an individual's present situation, the biographical approach emphasizes the placement of the individual within a nexus of social connections, historical events and life experiences (the life history) " (Miller R., 2005). Ogurtsov A.P. interpreted biographical method as "... one of specific methods of private papers analysis when materials that reflect person's participation in some social events and his attitude to them are gathered and generalized to solve some problem" (Ogurtsov A.P., 1990). Jaspers K. researched biographical method potentials both in psychology (Jaspers K., 1960), and philosophy (Jaspers K., 2013). Emelyyanov B.V and Lyubutin K.N. analyzed how to analyze philosopher's view by means of studying his biography (Emelyyanov B.V., Lyubutin K.N., 1987). In his turn, Garin I.I proved that philosopher's personality has an effect on his philosophy. He wrote that "the nature of philosophy's creator, structure of his consciousness, unconscious motives of philosophizing, thinking productivity play the core role in creating one or another philosophy" (Garin I.I., 2001). When writing this paper the ideas of above-mentioned authors concerned with essential features of biographical method, its potentials in historical and philosophical studies were used.

\section{Method}

The following methods were applied as main research methods: analysis, synthesis, generalization, typology, method of historism. Analysis and synthesis allowed revealing essential features of biographical method, its advantages and disadvantages, getting an integral idea of this method potentials in historical and philosophical studies. 750 biographies of well-known philosophers, living during various historical epochs and in different countries, were analyzed. Generalization defined logical-methodological procedures for using this method in various studies. Typology made it possible to distinguish typical features common to philosophers and compile their generalized portrait. Historism method allows considering biographical method application in the cultural and historical context of philosophical teachings appearance and development. We applied methods of Thompson P. (Thompson P., 1993) and Hoffman A. (Hoffman A., 1993).

\section{Results}

Biographical method is a set of means, techniques, regulators, which organize and guide the process of philosophers' life studying by means of researching their personal papers that reflect philosophers' behaviour causes in specific real-life situations and their attitude as well. It causes the need for studying philosophers' biographies. Biography is a philosopher's life from the moment of his birth to the moment of his death. It's based on various documents. Dilthey W. wrote, "documents a biography is largely based on are remains keeping person's expression and actions. Certainly, among them letters and certificate hold a specific place. A biographer, basing on such papers, has a task to comprehend the structure of an action, where an individual is defined with his environment and responds to it" (Dilthey W., 1992). The application of biographical method in historical-philosophical studies involves studying personal, official and secondary documents relating to philosophers' life.

Studying philosophers' personal papers. Philosophers' personal papers are autobiography, memoirs, confessions, intimate diaries, personal letters. Denzin N. stated, "life history materials include any notes or papers, including case stories, social organizations, which cast light upon individuals' and groups' subjective behaviour. Such materials can vary from letters and autobiographies, from news reports to court records" (Denzin N., 1989). Most important personal documents are philosophers' autobiographies. They are life histories of philosophers composed by them. As a rule, they state main events of philosopher's life. Autobiographies can be written both at personal wish in order to share philosopher's life with readers or under the order of philosopher's publisher. For example, autobiographies of Russel B., Herzen A.I., Berdyaev N.A., Bulgakov S.N., Wundt W., Cardano G., Rogers C. (Rogers C., 1967), Sorokin P.A., Spenser G, etc. stir researchers' great interest. Another significant personal paper is philosophers' memoirs (reminiscences). Memoirs are philosophers' notes of bygone events they took part in or were their contemporaries. In memoirs the author is less focused on his personal judgements and experience, so it's the main difference of memoirs from autobiographies. As a rule, they largely describe different events, an attempt to analyze them objectively is made. Many philosophers wrote memoirs, the most well-known ones are reminiscences of Gandhi M., Kropotkin P.A., La Rochefoucauld F., Lossky N.O., Seneca, Solovyev V.S., Stepun F.A., Strakhov N.N., Florensky P.A., Cesar , etc. Another personal paper is philosophers' confessions. Confession is a specific genre of literature that reveals philosopher's intimate affections, his 
repentance. The most famous confessions are Augustin's, Abelard's, Russo's, Tolstoy's. Philosophers' intimate diaries are also important personal documents. They reflect sequence of life events by days, weeks, months, years, etc., philosophers' reflections, estimation of current issues. One of most well-known ones are Krishnamurti's Notebook. Philosophers' personal letters present certain interest. They also describe individual aspects of their private life, subjective estimations and experiences of some events and life circumstances are given. In letters not only information about author but also its recipient, author's relations with other people are important. For example, there's letters of Bakunin M.A., Clark C., Solovyev V.S., Spinoza B., Chaadaev P.Ya, etc.

The study of official documents that reflect philosophers' life. They include archive records, vital records (year of birth, death, marriage, etc.), personnel record cards, formal organization characteristics, records on rewards or penalties, clinical records and cards, etc.

The study of secondary documents that reflect individual moments of philosophers' life. They include philosophers' contemporaries' memoirs, letters of people corresponding to philosophers, newspaper reports, philosophers' rough works, working plans, day regimen, etc., questionnaire-forms filled by philosophers, records of philosophers conversations with other people, records of financial receipts and expenses, characteristics of philosophers by other people, philosophers' biographies composed by their biographers, etc.

Application of biographical method in historical and philosophical studies allows detecting how life circumstances influence formation, development and sometimes changes of philosophers' views. Garin I.I. stated that "a person precedes philosophy, a person is a prerequisite of any philosophical cognition. It's impossible to understand philosophy out of personality: it is possible to recognize the idea only by gaining an insight into thinker's soul" (Garin I.I., 2001). Studying philosophers' biographies allows detecting its effect on world-view by the following main periods of philosophers' life:

- the period of beginning of philosophy studying (at this stage of life such biographical factors as personal abilities and proneness; relatives', friends' influence; mentors' and teachers' influence have major influence);

- the period of philosophical views formation (the following biographical factors influence philosophical views formation: getting certain type of education; relatives', friends' influence; mentors' and teachers' influence; reading books of specific philosophers;

- the period of philosophical views development (the following biographical factors influence philosophical views development: getting all-round education; social network involving other philosophers; extension of experience; affiliation to certain schools of thought; presence of crisis on philosophers' life);

- the period of philosophical views change (the following biographical factors influence philosophical views change: studying philosophical theories and acquaintance with philosophers at certain stage of life; rupture of friendly relations with some philosophers and enmity with others; devotion to certain popular philosophical theory; health status change; running of practical experiments; experience accumulation; understanding of philosophers' own mistakes and attempt to rectify them; authorities and religious organization pressure; presence of vivid, dramatic events in philosophers' life);

- the period of ending of philosophy studying (it takes place as a result of the following biographical factors: spiritual crisis or commotion, devotion to religion, alcoholism or drug dependency, devotion to other kinds of life activities, severe disease).

Biographical method as a method of historical and philosophical research has comprehensive heuristic opportunities, provides greater reliability, validity and feasibility of acquired data. It allows carrying out the following: to comprehend formation and development of philosopher's theoretical views in the context of his life; to provide reliability when studying facts and events in philosophers' life; to reproduce crucial, unique moments in philosophers' life, which cause the change of his views in a certain life situation; to understand philosophers' behaviour reasons, mechanisms, motives in some or other life situations; to research philosopher's biography within his own understanding; to understand philosopher's attitude to most important events and phenomena of social life, to contemporaries; study his personal estimation of social realm; to "humanize" historical and philosophical material about philosophers' life, their theoretical view of the world and himself within that world; to compile philosophers' biographically complete, social-psychological portraits, to describe their common and unique features.

The heuristic potentials of biographical method are limited to some extent by this method disadvantages. They are subjectivity of philosophers' autobiographies, memoirs and confessions, insufficient representativeness of biographical researches, incompleteness of philosopher's life biographical moments; certain dependency of philosophers' biographies statement on social environment, on circumstances, sentiments of historical epoch. At the same time it's possible to overcome the drawbacks of biographical methods: firstly, using such biographical sources as official and secondary documents, reminiscences of pupils and followers, etc.; secondly, massovization of biographical materials attracted for 
studying (studying a great number of philosophers, this paper analyzes biographical facts of 700 philosophers; the names of philosophers included in this list were defined according to philosophical encyclopedic dictionary, other philosophical and biographical dictionaries); thirdly, using information on philosophers that was obtained by their biographers, philosophy historians; fourthly, applying the following research methods as additional ones: cohort analysis, content analysis, classifying method, typology, etc.

Biographical method involves detection of the following facts in philosophers' life: social background and status; inborn aptitudes, character; education; specialization; appearance, behavior pattern; lifestyle, manner of philosophizing; circle of contacts, attitude to predecessors; hobbies; social and political activity; attitude to family, woman; distinct, crucial moments in life; death, lifetime; personal rewards.

Biographical method allows detecting special, crucial moments in many philosophers' life (spiritual crisis, commotion, hallucinatory state, prophetic dreams and revelations, etc.), which contributed to appearance of the interest in philosophical meditations, the change of world outlook, disappointment in philosophy. For example, without regard to crisis moments in the life of Bulgakov S.N., Hamann N., Dostoevsky F.M., Croce B., Nietzsche F., Pascal B., Socrates, Tolstoy L.N., Unamuno M., Fichte I., Chaadaev P.Ya. and many others it's impossible to comprehend their philosophic theories.

Biographical method makes it possible to compile the generalized portrait of the philosopher. The philosopher is a person who reaches after ultimate, universal clarity and truth. Many philosophers stated that one needs to be born a philosopher, i.e. a person should originally have specific personal qualities. For example, Socrates, Plato, Nietzsche stated that philosophy is for the chosen. Sophists (Protagoras, Gorgias) considered that philosophy can be taught and took money for philosophy teaching. Probably, those who stated that this problem can be solved by distinguishing philosophy and philosophy were right (Hegel, Popper K.). The first meaning implies studying philosophy as a science, everyone can do it. The second meaning implies searching after truth, wisdom. In this case philosophy isn't outcome of studies, but the result of person's experience and attitude. It's peculiar to gifted people only.

The philosopher is a person, who, as a rule, was born in a better-off family, didn't experience material losses and severities, had an opportunity to study in good schools, could read many books kept in the home library, communicate with many interesting people. More often than not the to-be philosopher had a home tutor who planted love for sciences, philosophy. From earliest infancy he was known for inborn aptitudes, had tendency to reflections, reading, and was curious. The philosopher was characterized with tendency to contemplate the world around, frequent focus on selfexamination, self-observation. Many things set him wondering, aroused his wish to spy into the secrets of existence and life, "his philosophizing began from surprising" (Plato, Aristotle). Philosophizing also began from the moment when the philosopher realized certainty of his own death (Socrates), felt a need in "the conversation of soul with himself" (Plato), understood his weakness and debility before the huge world (Epictetus). As a rule, philosopher's parents had high social standing, belonged to the ruling or intellectual elite. Therefore, the philosopher got education in prestigious universities. He got both philosophical and non-philosophical education. That's why he became either a professional philosopher or a specialist in some other area philosophizing due to his interest or need. When studying in university, he communicated with many people, firstly, with his teachers-philosophers, with classmates and friends, who afterwards also became philosophers. He visited various philosophical classes, saloons, disputes, where his further development took place in the course of communication. The philosopher's first works were of compiled, as a rule, imitative nature - teacherphilosopher's impact manifested itself. Subsequently his works became independent. Critical attitude to previous philosophical concepts and their creators became the result of independent philosophical theories development. The philosopher aimed to formulate his own philosophical system, given this, all previous existing philosophical systems and concepts were repudiated. The philosopher didn't lack the elements of ego trip and self-glorification. He scarcely ever mentioned his predecessors or contemporaries well, they generally came under criticism, often acid and mordacious, that's why the philosopher was rarely on a friendly footing with people, more often enmity, disaffection and negation characterized his relation to other people. Studying philosophy didn't prevent the philosopher to engage in other kinds of activities, other sciences. He could be a politician, an ideologist, a write, a lawyer, a doctor and a scientists, etc. At the same time the only his love, main occupation and life avocation was philosophy, since "when philosophizing a person enjoys chief happiness" (Aristotle). Studying philosophy defined peculiarity of his life style. He preferred to lead a lonely life, often led armchair scientist's way of life. Philosophizing promoted development of philosopher's abstract thinking. The philosopher aimed to grasp the universal, the absolute form of existence. For this reason time and again he imaginatively traveled form the real world to the other world. He opposed the real world to the ideal, model world, which he considered the genuine one. Often his reflections became contemplative, unclear to the majority of surrounding persons, that's why the philosopher stated his ideas in imaginative, parabolic, epigrammatical form. He wasn't a stranger to humor, self-criticism. Constant tension of thought, discontent with himself, with the world around caused appearance of 
specific, crucial moments in philosopher's life, such as spiritual disturbance and crises, nervous breakdowns, rueful feelings and disappointments. He was often known for unbalanced behaviour described by exaltation of his theory and his person. His behavioral pattern was distinguished by distinct independence, ironically skeptical attitude to everything, desire to preach and teach surrounding persons. In its turn, it caused negative attitude to the philosopher. To increase the effect on the company philosophers took specific appearance, behavioral pattern. The philosopher was characterized by average height, heavy body-build, independent behaviour, desire to argue, speech skill, specific appearance, for example, having beard and moustaches, broad forehead, bright blue eyes, specific style of clothing, etc. Philosopher was skeptical about family and woman, since love for philosophy was so huge that there wasn't any place for love for woman, family, children. As a rule, the philosopher was single, an antifeminist, if he entered into marriage, it was generally unhappy. Love for philosophy was complemented with some hobbies such as chess, learning of languages, collecting, etc. As a rule, the philosopher scintillated witticisms, had a sense of humour. Many of his expressions were distinct in anecdotical nature, irony, paradoxicality. Humor attracted people, allowing philosophers to mock at them and, first of all, at themselves. The philosopher was critical about authorities. Generally, his road to power was unsuccessful. The philosopher usually proved genuineness of his theories by his lifestyle, he considered his own "life as an argument for confirmation of his philosophy right" (Schweizer A.). Philosopher's life was long, since he treated it as highest value, and attitude to death was easy and rational. As a rule, the philosopher contributed significantly to humanity's spiritual culture development, leaving grateful memory of himself.

Usually people, who reached the "equator" of life, 40-45 years old, became philosophers (acme - the most advantageous age for philosophizing). By this time they accumulated certain experience, began to analyze it and reflect upon spent years. Exactly at this time they began to ask themselves why do I live in this world, what have I achieved in this life, what does await me ahead. At this age a person begins to reflect upon the end of life, upon death. A matter of life and death is the most important factor that conditions philosophizing of any person. The person starts to reflect not about the outside world, but himself in this world. Once the issue of how and why to live is solved, philosophers begin to live by principles resulting from this solution. Philosophers are people living by a code, people who ready to protect their principles. Philosophers are people, who consciously choose certain lifestyle, behavioral pattern. Personal life example for them is main evidence for their views' validity. More often than not their only and unconditional love is philosophy itself, philosophy studying.

Philosophers are also known for qualities, which cannot be considered positive. It's common to philosophers to reflect upon the general, the abstract, than the particular, the real. Philosophers' irony and skepticism often offend common people. Berdyaev N.A. highlighted it. He stated that "the major part of people is ready to use the world "philosopher" in a mocking and reprobative meaning. And the word "metaphysics" is almost a swear in everyday life. A ridiculous figure is made out of metaphysics, and it actually can be ridiculous (Berdyaev N.A., 1994).

\section{Discussion}

Findings confirmed hypothesis we stated on the possibility to detect the life circumstances impact on philosophers' worldview, to compile philosopher's generalized portrait using biographical method. Their main significance is opportunity to "humanize" philosophers' world-view in the context of their life circumstances, to reveal the philosophers' biographies effect on formation, change and development of their views.

\section{Conclusion}

In the course of the research the issues requiring for further development are exposed: the need for more thorough and in-depth study of biographies of as many philosophers as possible, the study of the biographical factors impact on philosopher's world-view in various periods of his life. The following conclusions were made as a result of the study:

- biographical method is a method that organizes and guides the process of studying philosophers' life by means of personal, official and secondary documents research.

- biographical method has both advantages and (simplicity, reliability of findings, personal data verifiability) and some disadvantages (subjectivity of philosophers' autobiographies, memoirs and confessions, insufficient representativeness of biographical data,) which should be taken into account in the course of its application,

- biographical method has vast heuristic potentials as it helps understanding formation and development of philosopher's views in the context of his life, compiling philosopher's generalized portrait, distinguishing his main features (inborn aptitudes, search for truth cognition, ironical and skeptical attitude to the world, rationalism and criticism of thinking, escaping from reality, focus on self perception). 


\section{Acknowledgments}

We would like to express our gratitude to Associate Professor of Philosophy and Sociology Department of the Elabuga Institute of Kazan Federal University Gromov E.V. for provided biographical materials about Russian philosophers.

\section{References}

Berdyaev, N.A. (1994). Philosophy of free spirit. Moscow.

Biographical method in sociology: history, methodology, practice (1993). / Ed. by Semenova V.V., Mescherkina E.Yu.

Bühler, Charlotte (1972). Selbstdarstellung. In: Ludwig Pongratz u. a. (Hrsg.): Psychologie in Selbstdarstellungen. Band 1. Huber, Bern u. a. S. $9-42$.

Denzin, N. (1989). The Research Act. A Theoretical Introduction to Sociological Methods, 3rd ed. Englewood Cliff. Prentice Hall.

Devyatko, I.F. (1994). Biographical method /I Methods of sociological studies - Ekaterinburg: Ural University Press, 256 p.

Dilthey, W. (1992). Gesammelte Werke. Bd. VII. - Stuttgart.

Diogenes Laertius (1979). Lives of Eminent Philosophers. Moscow.

Emelyyanov, B.V., Lyubutin, K.N. (1987). Introduction to philosophy history. Moscow, 160 p.

Erben, Michael (1996). The purposes and processes of biographical method. In, Scott, David (ed.) Understanding Educational Research. London, UK, Routledge, 159-174 pp.

Fichte, J. (1993). Essays in 2 volumes. Vol.1. St. Petersburg.

Fuchs-Heinritz, V. (1993). Biographical method // Biographical method in sociology: history, methodology, practice / ed. by Semenova V.V., Mescherkina E.Yu. Moscow, pp. 11-41.

Garin, I.I. (2001). What is philosophy. Moscow: Terra, 752 p.

Gay-Voronskaya, A. (2015). Biographic Method and its Heuristic Potential in Sociological Research. http://elib.bsu.by/bitstream/ 123456789/8636/1/.pdf.

Hoffman, A. (1993). Consistency and reliability in oral history // Biographical method in sociology: history, methodology, practice / ed. by Semenova V.V., Mescherkina E.Yu.. Moscow, pp. 42-50.

Jaspers, K. (1960) Phychologie der Weltanschauungen. Berlin, Gottingen; Heidelbtrg. Springer Verlag.

Jaspers, K. (2013). Prominent philosophers. Buddha, Confucius, Lao-tzu, Nagarjuna. Moscow, 240 p.

Miller, R. (2005). Biographical research methods. Four-Volume Set. Series: SAGE Benchmarks in Social Research Methods. 2005. Date Views 11.12.2013. srmo.sagepub.com/view/the-a-z-of-social-research/n6.xml.

Misch, G. (1949). Geschichte der Autobiographie. Bern.

Ogurtsov, A.P. (1990). Biographical method. // Modern western sociology: dictionary. Moscow: Politizdat, p. 36.

Rogers C. (1967). Autobiography // Boring E.G., Undzey G. (eds.). A history of psychology in autobiography. V. 5. N.Y.: AppletonCentury-Crofts, pp. 341-384.

Rozhdenstvenskaya, E.Yu. (2012). Biographical method in sociology. Moscow: Higher School of Economics Press.

Sabirov, A.G. (2013). Specific Character and Functional Potential of Social and Humanitarian Cognition Methods // Middle-East Journal of Scientific Research 17 (3): 292-295.

Sabirova, F.M. (2013). Opportunities of Biographic Method in Improvement of Physics Teacher Training/l World Applied Sciences Journal 27 (Education, Law, Economics, Language and Communication): pp. 294-298.

Solovyev, E.Yu. (1981). Biographical analysis as a type of historical and philosophical studies. http://scepsis.net/

Thompson, P. (1993). History of life and analysis of social changes // Voprosy sotsiologii. \# 1-2. pp. 129-138. 